ISBN 978-81-933894-1-6

International Conference on Arts, Social Sciences, History and Interdisciplinary Studies

(ASSHIS-2017)

Kyoto (Japan) April 20-21, 2017

\title{
Online Purchasing Behavior for Clothes, Bangkok
}

\author{
Mr. Lei Qian, Dr.Chinnaso Visitnitikija \\ Gaduat School of Business Administration Kasembundit university, Bangkok
}

\begin{abstract}
This research aims to study the behavior and marketing factors related to online purchasing behavior for clothes, as well as the marketing mix and purchasing behavior. The research is a quantitative research with a research population of 385 online clothes purchasers and a questionnaire as the main research tool. The statistics used for the data analysis are descriptive statistics such as frequency, percentage, means, standard deviation, Chisquare and regression analysis.

It is found that the majority of the 385 questionnaire respondents are women 20-29 years old. Most of them are single and have a bachelor's degree. Their average monthly salary is approximately 30,001 - 40,000 baht. Most of them have bought clothes online for 3-4 years. The products they buy are fashionable clothes. Their main reason for purchasing online is that they can compare numerous types of clothes on the internet. They acknowledge information from advertisements in different media. Mostly, they visit Alibaba to buy clothes online. In most cases, they buy clothes online 6-8 times/year. The value of online clothes purchases for each time ranges from 501 to 1,000 baht or higher. The payment method is money transfer via the bank. The marketing mix factors of online clothes purchases with regard to product, price and distribution channel have the highest impact. The impact of marketing promotion was high. Different personal attributes affect purchasing behavior with respect to the life span of products, product categories, reason for purchasing, influencer in purchasing, payment method, purchasing frequency and purchasing value. The marketing mix factors are related to purchasing behavior in terms of wide price range of products, payment method, convenient goods, and marketing promotion such as recommendations from website posts, shares, likes and comments of the service users.

As for the recommendations for further study, distributers should frequently update their products so that their products are always fashionable and can respond to the customers' demands. The price should be cheaper than the price of products of other sources. The distributers should offer products of different price ranges. The customers should be able to compare numerous products and conveniently choose and search for their desired products. The selected products should be conveniently and quickly delivered. New products with special prices should be regularly introduced to the customers. Sales promotions should be often made. And the products should be recommended via website posts, shares, likes and comments of the service users.
\end{abstract}

Keyword: Product Behavior

\section{Introduction}

The Internet is very important to the way we live today in every aspect. Whether people in business, education, the Internet has benefited from it today. Online media is a means to reach consumers quickly. Also accessible at any time. And online media users.

The group has high spending power for consumption. In addition, the Internet is as important as: Search for information. To help with business decisions. Can trade Network transaction And as a channel to promote advertising, business communications, corporate users. Or organizations It can be opened. And support their customers through the Internet.

The reason why online business boom is so fast nowadays is that most businesses do not have to spend huge amounts of money to invest. The start-up process is not as complicated as it used to be. This resulted in a new entrepreneur. Especially in B2C (Business to Consumer)

Gradually step into a new player. In this market more. Clearly, the market is in fashion and apparel. The National Bureau of Statistics (NBS) has unveiled survey figures (in 2011) that over $70 \%$ of new online 
entrepreneurs are competing in this glamorous fashion segment. (Currently, the market value reaches over 20 billion baht per year).

The clothing business is gaining popularity in the consumption of goods through online media. For reasons such as cheaper prices. Because the seller can reduce the cost, the other parts are convenient, do not have to travel. Product integrity is immediately available through the product review.

And many other reasons for the above reasons. This makes the business interested in the clothing business on the online network that is popular today. And is growing steadily. Therefore, there is a need to study the study of online clothing shopping behaviors. As a guideline for the online garment business. And promote the use of technology to integrate into the business.

\section{Purpose of Study}

1. To study the buying behavior of clothing online.

2. To study the marketing factors affecting online clothing selection.

\section{Research Method}

Resources include: Primary data sources and secondary data sources The population used in this study were 385 online shoppers.

Result study Most of the 385 online shopping habits Female age is in the range of 20-29 years. Single status of education is in the bachelor's degree. Monthly income is in range. 30,001-40,000 Baht Most used to buy clothing online for 3-4 years. The reason for the purchase is that there are a variety of products to compare with the information from most media ads.

Alibaba website to buy clothes. The frequency of purchase is 6-8 times per year. The value of each online clothing purchase is approximately 501-1,000 Baht and use the payment method by bank transfer.Marketing mix factors affecting decision making behavior in clothing selection.

On the online network, the overall average of all aspects is the highest level. Product consistency is the highest level, consisted of up-to-date products, always up-to-date products. Have a product that meets your needs. And there are enough stock to meet the demand. The price level is the most agreeable level, the product is available in several price levels. Can buy cheaper than other sources.

And how to pay for goods convenient. The distribution channel in the most agreeable level is the introduction of new products at special prices. Can compare products. It is easy to shop and find products. Open 24 hours and replace the problematic product. Marketing promotion is very agreeable level is the introduction of post (Post) Share (share) Like (Comment) of the user. Promotion is always available. And the seller offers a shopping guide.

Test results hypothesis Price factor There are many levels to choose from. Payment for goods convenient. And marketing promotion. In the introduction of the Post (Post) Share (Like) Comment of the user. There is a correlation between marketing mix and online buying behavior. At statistically significant level 0.05

\section{Discussions}

To study Online clothing shopping habits purpose To study the buying behavior of online clothing. And to study the marketing factors affecting online clothing selection. Using quantitative methods. (Quantitative Research) The study instruments were 385 questionnaires.

Statistics used in data analysis are frequency, percentage, mean, standard deviation (SD), chi-square, and regression analysis. There were 385 questionnaires.

The marketing mix that influenced the overall decision making behavior of online clothing was at the highest level, with the highest level of overall product consistency. The overall price level is at the most 
agreeable level. The distribution channel is at the most agreeable level. The marketing promotion aspect is very agreeable.

\section{Suggested study}

The researcher has suggested the following study: Product Online clothing distributors should focus on upto-date products, always up-to-date. And there are products that meet the needs of consumers. The price of clothing distributors on the online network should be cheaper than other sources.And the products are available in several price levels. Distribution channels, clothing distributors on the online network should have a variety of products. Consumer Comparison Shopping and shopping convenience. Delivery convenient and fast. And introduce new products at special prices to consumers. The promotion of online clothing distributors online should be promoted. All the time and the advice of the post (Post) Share (Like) Comment of the user.

TABLE I: The results of hypothesis testing on relationship between marketing mix and online shopping behavior.

\begin{tabular}{|c|c|c|c|c|c|c|}
\hline \multirow[t]{2}{*}{ Marketing mix } & \multicolumn{2}{|c|}{$\begin{array}{l}\text { Unstandardized } \\
\text { Coefficients }\end{array}$} & \multirow{2}{*}{$\begin{array}{l}\text { Standardized } \\
\text { Coefficients } \\
\text { Beta }\end{array}$} & \multirow[b]{2}{*}{$\mathrm{t}$} & \multirow[b]{2}{*}{ Sig. } & \multirow[t]{2}{*}{ Test result } \\
\hline & B & $\begin{array}{l}\text { Std. } \\
\text { Error }\end{array}$ & & & & \\
\hline $\begin{array}{l}\text { (Constant) } \\
\text { Product side } \\
\text { Product is updated (Up Date) } \\
\text { Always } \\
\text { Always up-to-date. } \\
\text { Have a product that meets your } \\
\text { needs. } \\
\text { There is enough stock to meet } \\
\text { demand. } \\
\text { Price } \\
\text { Can buy cheaper than other } \\
\text { sources. } \\
\text { Products are available in several } \\
\text { price levels. } \\
\text { Can agree on the price easily. } \\
\text { How to pay for goods convenient. } \\
\text { Distribution channel } \\
\text { It is easy to shop and find products. } \\
\text { Fast and convenient delivery } \\
\text { service. } \\
\text { Can compare products. } \\
\text { Open } 24 \text { hours. } \\
\text { Introducing new products at special } \\
\text { prices. } \\
\text { Can replace the product that has } \\
\text { problems. }\end{array}$ & $\begin{array}{c}1.935 \\
-.096 \\
0.71 \\
-.007 \\
.018 \\
\\
.042 \\
.137 \\
-.004 \\
.148 \\
\\
-.011 \\
-.069 \\
.080 \\
.002 \\
-.122 \\
.051\end{array}$ & $\begin{array}{l}1.136 \\
.076 \\
.062 \\
.050 \\
.059 \\
\\
.060 \\
.070 \\
.048 \\
.070 \\
.064 \\
\\
.068 \\
.058 \\
.055 \\
.069 \\
.057\end{array}$ & $\begin{array}{l}-.066 \\
.059 \\
-.007 \\
.017 \\
\\
.037 \\
.113 \\
-.004 \\
.112 \\
\\
-.009 \\
\\
-.056 \\
.071 \\
.002 \\
-.093 \\
.046\end{array}$ & $\begin{array}{c}1.703 \\
- \\
1.264 \\
1.149 \\
-.137 \\
.314 \\
\\
.700 \\
1.970 \\
-.075 \\
2.117 \\
-.169 \\
- \\
1.023 \\
1.372 \\
.034 \\
- \\
1.766 \\
.888\end{array}$ & $\begin{array}{l}.089 \\
.207 \\
.251 \\
.891 \\
.754 \\
\\
.485 \\
.050^{*} \\
.941 \\
.035^{*} \\
\\
.866 \\
.307 \\
.171 \\
.973 \\
.078 \\
.375\end{array}$ & $\begin{array}{c}\text { no } \\
\text { no } \\
\text { no } \\
\text { no } \\
\text { no } \\
\text { relation } \\
\text { no } \\
\text { relation } \\
\\
\text { no } \\
\text { no } \\
\text { no } \\
\text { no } \\
\text { no } \\
\text { no }\end{array}$ \\
\hline
\end{tabular}


TABLE II: Show the results of the hypothesis testing on relationship between marketing mix and online shopping habits (cont'd).

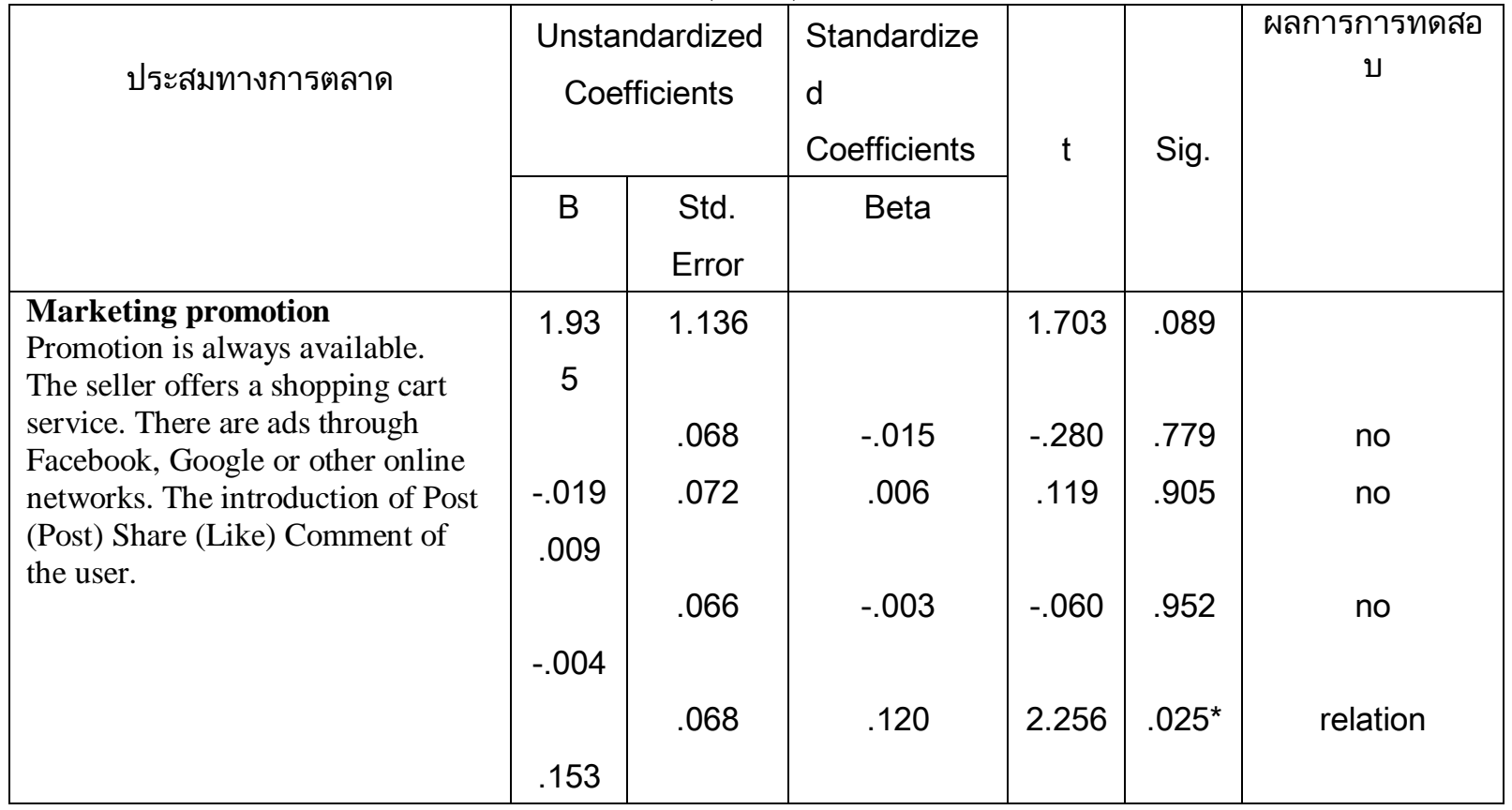

The results of the hypothesis testing on the relationship between marketing mix and online shopping behaviors showed that:Price (Price) Products are available in several price levels. (Significant level $=0.050$ ). Payment method convenient goods. (Significant $=0.035$ ) and Promotion (Promotion) is recommended by Post, Share, Comment, (Significance $=0.025$ ). There was a correlation between the marketing mix and the online shopping behavior. At significance level 0.05

\section{References}

[1] Social Networking Online (2556) https://sites.google.com/site/is4054is/home.

[2] Veeranuch shimmer.(2556) Internet shopping behavior among teenagers.

[3] A thesis on the Master's degree program in home economics, Rajamangala University of Technology Phra Nakhon.

[4] Sukanya Chinphai (2555) Consumer behavior towards the clothing business on the social network ofUniversity student Chiang Mai University. Chiang Mai University.

[5] Siriwan Serirat. (2001). Consumer Behavior. Bangkok: Wisitwattana.

[6] Siriwan Serirat and Amornsak Boonrueng. (2003). Modern Marketing Management. Bangkok: Diamond in business world. 